\title{
TRANSPARENȚA CA POSTUMANISM: O RESTAURARE A OMULUI ÎN LITERATURĂ
}

\author{
Bianca Maria Partenie \\ partenie.maria@yahoo.ro \\ Universitatea din București
}

\begin{abstract}
The present study aims to encapsulate the emergence of the posthumanism (and of the posthuman, implicitly), seen as profoundly human, in Radu Vancu's Transparența. The starting point for selecting the characteristics of such a posthumanism peculiar to Radu Vancu is represented by his literary study Elegie pentru uman: o critică a modernității poetice de la Pound la Cărtărescu. From his analysis upon the antihuman side of modernity's project, I extract the four typologies through which literature has fought against (the social, political and artistic) dehumanization: corporeal, confessional, maximalist and sacred. Following at the same time Elegie pentru uman and Transparența I reach the conclusion that Radu Vancu uses in his novel all the aforementioned typologies in his project to restore the human. In other words, Elegie pentru uman, in its first part, is, in a way, an ars poetica, a drawing in nuce of the forthcoming novel. To this group of four typologies enlisted by Radu Vancu, I will add one more, peculiar to his writing, which emerges from the study as well as from the novel: poeticality.

The fifth category looms in the novel's writing and in the reference to Ion Mureșan within Elegie pentru uman. Ion Mureșan described literature as the immune system, while the poets are seen as the antibodies of society. Thus, the poeticality within the novel is an immune system which helps the restoration of the human, becoming a key element of the posthuman fiction in Radu Vancu's text.

The second part of the study will focus on the close reading of the function of some fictional objects in the posthuman narrative of Transparența. The selected fictional objects are the ones which are vital for the human salvation from the dehumanizing ghosts of recent history. Such fictional objects are: the body, the light, the text, the reader, Mega, Sibiu etc. Seen through the filter of a posthumanism deeply human at its core, the novel presents the story of a narrator who whishes to restore his lover and, implicitly, the whole world. To conclude in Dostoyevskian terms: humanity will save the world.
\end{abstract}

Key- words: posthumanism, posthuman, restoration, fictional objects, corporality 
Postumanismul- o restaurare a omului

Postumanismul este încă un spațiu în plină cartografiere, ce își subsumează multiple definiții, alături de termeni conecși precum: post-omul, post-umanitate, post-istorie etc. De la accepțiunea ,,pesimiștilor de serviciu’, după cum îi denumește Bogdan-Alexandru Stănescu (193196), precum că postumanismul marchează un nou sfârşit al omului (distrus o dată de proiectul modernității, acum va fi distrus de propria-i creație) la optimiștii care văd noul cadru ca pe o îmbunătătire tehnică și tehnologică a tot ce înseamnă uman și umanitate, postumanismul rămâne o fascinantă poveste.

Profitând încă de această formare a ceea ce ar putea însemna postumanul și postumanismul, lucrarea de față își propune să găsească o posibilă definiție a acestuia în spaţiul românesc literar, mai precis în două dintre textele lui Radu Vancu: Elegie pentru uman: o critică a modernității poetice de la Pound la Cărtărescu și Transparența.

Conturarea cadrului postuman, privit din perspectiva lui Radu Vancu, își are originile în trei puncte conexe: filiera filosofică (the French Theory, eul ca ficțiune și moartea omului anunțată de Foucault), filiera tehnologică și filiera redefinirii relației dintre om și natural/natură (înlocuirea biosului de către zoe, detronarea omului din poziţia sa centrală și autoritară asupra întregii creații). (Vancu 68-69) Astfel, postumanismul are de ales între două direcții în revolta sa contra normativului uman: ,(...) ca pe o formă de ură împotriva omului concret (ceea ce ar fi o repetare a erorii majore a modernității) - sau, dimpotrivă, ca pe o exportare a valorilor pozitive ale umanului (empatia, compasiunea, solidaritatea) înspre zonele non-umanului (ceea ce ar fi realmente o corijare en beaute a acelei erori).', (69-70)

În finalul articolului său, Radu Vancu scrie:

Sper, așadar, ca postumanul să nu fie o formă de Hassliebe pentru uman- ci un mediu de proiectare a valorilor reale ale umanului (empatia, compasiunea, solidaritatea, așa cum am spus mai sus) asupra non-umanului. Înțeles astfel, e o enormă șansă. Înțeles ca o vindicație la adresa umanului, ar fi o catastrofă. (70)

Așadar, pentru Radu Vancu postumanismul devine o șansă de recuperare a tot ce are umanitatea mai bun de oferit, șansa pentru o readucere în arte a figurii umane. $\mathrm{Cu}$ această idee în minte voi citi analiza proiectului modernității din Elegie pentru uman. Din această perspectivă, se observă că rădăcinile a ceea ce Radu Vancu numește postmodernitate (din care postumanismul face parte) se află în lupta literaturii împotriva anti-umanului modernității. 
Confruntată cu o anihilare a umanului atât per se (prin ideologiile totalitare și lagărele de exterminare la care acestea au dat naștere), cât și o exilare a acestuia din arte, postmodernitatea (în care postumanismul devine una dintre expresiile sale) va încerca să reîmblânzească aceste teritorii și să reintroducă, treptat, figura umană. Răspunsul literaturii în faţa evacuării umane a vizat patru paliere de acțiune, pe care Vancu le enumeră în studiul său după cum urmează: corporalul (de aici se desprind corporalii- autorii care au gândit și privit lumea ca pe un corp), confesivul (scriitura confesivă), maximalul (maximaliștii care încearcă să se opună pulverizării valorilor prin o integrare cât mai vastă a acestora în literatură. De aici și romanele maximaliste, idee dezvoltată de Stefano Ercolino și despre care Vancu scrie .) și sacrul (sacralii).

Aceste patru categorii se regăsesc, de data aceasta puse în aplicare, în romanul Transparenţa. Naratorul poveștii privește atât lumea, cât și textul, ca pe un corp viu, cu multiple seturi de valori umane (atât pozitive, cât și negative- ilustrate prin dialogurile și polemicile cu el capitan). Stilul său de a scrie este unul confesiv, în timp ce manuscrisul pe care îl redactează are, în fond, o profundă legătură cu sacrul și o miză uriașă: acela de a aduce la viaţă, de a reda corporalitate Megăi și, prin extensie, întregii lumi. Pe lângă cele patru categorii de restaurare a umanului, pe care le voi subscrie unei definiții a postumanismului la Radu Vancu, se mai distinge o a cincea. Aceasta nu apare numită în studiul literar al autorului, dar este prezentă latent la rădăcina textului: poeticitatea.

În partea a doua a acestei lucrări voi remarca importanța pasajelor profund poetice în scriitura Transparenței. Această poeticitate are o dublă funcție: atât intratextuală, cât și extratextuală. Pentru moment, voi explica doar valența extratextuală a poeticității, ce se înscrie în categoria de trăsături ale postumanismului.

În Elegie pentru uman, Radu Vancu face trimitere la Ion Mureșan care, la un moment dat, denumește literatura drept sistem imunitar, în timp ce poetul este anticorpul acestui sistem. Astfel, cu un postumanism ce își are originea în lupta contra dezumanizării, poeticitatea, prin analogia cu viziunea lui Ion Mureșan, devine o modalitate de a rezista acestei anihilări.

Cu o conturare în substrat a ceea ce înseamnă postumanul și postumanismul pentru Radu Vancu, Elegia pentru uman devine, cel puțin în prima sa parte, un fel de ars poetica, o schiță a Transparenței. Cele două texte comunică între ele, Elegia conținând germenii viitorului roman. Aș spune chiar că cele două cărți se construiesc reciproc în ideea în care Elegia prefigurează planul Transparenței, în timp ce Transparența materializează tipologiile de rezistență împotriva antiumanului. 
În continuare, voi analiza Transparența prin aplicarea celor cinci categorii și selectarea elementelor din imaginarul narațiunii care conțin o semnificație importantă în construirea universului postuman și în conturarea postumanismului la Radu Vancu.

Elementele corporalului, maximalismului, confesivului, sacralității și poeticității în Transparența Universul din Transparența este o post-lume. De ce? Pentru că ne aflăm în anii de după '90, într-o Românie distrusă de planul dezumanizant al modernităţii, o lume în care omul a fost scos în afara istoriei, artelor și religiei. Avem în față lumea de după finalul proiectului politic modernist -o lume rămasă în viață după o dezlănțuire de ani întregi a terorii. De aceea ea este o post-lume- face parte din tot ceea ce a mai rămas postmodern, din ceea ce a mai rămas după '89. (Înțeles ca bornă în spațiul ficțional al romanului ce marchează eșecul proiectului modernității și intrarea într-o altfel de lume.)

Pe acest fundal, plin de confuzie și dezorientare, naratorul nostru vine cu propria-i istorie, o poveste ciudată. În copilărie, află că poate deveni transparent atunci când trăiește emoții profunde, fie negative, fie pozitive. Încercând să afle răspuns la mutația sa genetică, el își identifică o serie de strămoși care, pe cale artificială (artă sau sinucidere) au încercat să atingă invizibilitatea. Astfel, transparența devine o formă de transcendență, o formă de a ieși din realitatea ireală a anilor de după '90. Realitatea devine ireală după decenii de teroare. Ceea ce se petrece de la Al Doilea Război Mondial până în prezentul narativ al poveștii este atât de plin de cruzime, încât nu are cum să fie real. Trebuie să existe o altă realitate în spatele acestei irealități construite de ani de teroare și de cenzură, de anihilare a umanului în comunism. Iar singura cale de a ajunge la realitatea reală este transparența.

Această confesiune a unui transparent are drept ultim scop restaurarea omului și redarea unei corporalități transparente Megăi și lumii. (Mega fiind lumea naratorului, neurotransmițătorul după care universul se ghidează.) Astfel, forța motrice care conduce această narațiune este iubirea.

Am ținut să rezum această parte a povestirii pentru o mai bună înțelegere a analizei ce va urma. Însăși această rezumare a evenimentelor conține în sine o interpretare: aceea a ideii de postlume în cadrul romanului, a ideii de ce înseamnă forma postumană (transparența) și a ideii de real ce vizează o lume (dincolo) de realul marcat de urmele modernității încheiate, o lume nouă ce se va construi odată cu înțelegerea ca transparență, ca marker al profundei umanități ce va izbăvi lumea. 
Prima categorie analizată este corporalitatea. Regăsim în text trei conjugări ale corporalității: corporalitatea naratorului, corporalitatea text-lumină-cuvânt și corporalitatea lumeSibiu-Mega. Voi lua pe rând fiecare corporalitate și o voi analiza îndeaproape.

Corporalitatea naratorului- invizibilitatea ca monstruozitate

În legenda invizibilității naratorului totul începe la cutremurul din 1977, o Bună Vestire a transparenților. Această interpretare a faptelor o primim de la femeia de serviciu a grădiniței unde povestitorul merge, copil fiind. După ani buni de teroare, umanitatea, văzută ca un organism complex, conectat la un creier nevăzut, uriaș, în urma spaimei trăite, reușește să își modifice ADNul și să creeze o genă mutantă în propria evoluție: invizibilii.

- „Vrei să spui că tu chiar crezi că evoluția a fost posibilă numai grație terorii? Că tranziția de la o specie la alta a fost făcută posibilă de teroare? Ba chiar și tranziţia între regnuri? (...)

- (...) Dar cred că, dacă îți reprezinți și literatura, și natura ca pe niște creiere gigantice, teroarea e principalul lor neurotransmiţător.

(...)

- Însă ce spune Vancu e că, de fapt, nu există două creiere separate, unul al literaturii, altul al naturii. Ci că ele sunt același creier- și că a ajuns să existe, la proporțiile astea monstruoase, la capătul unui șir de linii evolutive pe care teroarea le-a făcut posibile - și pe care tot ea le-a menţinut active, și pe care tot ea le-a făcut să transgreseze exact atunci unde și când trebuia.” (...)

Teroarea devine catalizator pentru evoluția umană, care va reuși să preia de la regnul animal și vegetal o anumită poziționare a cristalelor guanine, care, prin captarea luminii, va produce efectul de invizibilitate:

„Oricât de diferite între ele sunt speciile, mecanismul e același: pielea lor conține câteva straturi de nanocristale guanine, îmbrăcate într-un săculeț de iridofore dermale. Micile cristale fotonice de guano își pot adapta distanţa dintre ele astfel încât să reflecte alte lungimi de undă ale luminii; sunt practic ființe care se adaptează nu la mediu, ci la lumină, profitând de un mecanism simplu, pe care evoluția li l-a pus la îndemână. (...) În schimb, puținele ființe care au făcut pasul normal către sintetizarea de cromatofore dermale din guanina pe care corpul lor o conţinea din belșug sunt bizareriile lumii de azi și dintotdeauna, cele pe care Darwin, în capitolul despre variația sub influența naturii din Originea speciilor, le-a încadrat drept monstruozităţi definindu-le drept deviații de structură lipsite de utilitate pentru specie (...)."

Este de remarcat termenul de ,,monstruozitate'. Eu 1-aș citi în cheia pe care o face și Gheorghe Crăciun când vorbește despre „monstruozitatea autorului’’ (înțeles ca eu scriptor în cadrul narațiunii). Pornind de la sensul etimologic al cuvântului, monstruozitatea este înfățișarea 
eului în toată goliciunea sa: ,,Tot ceea ce se dă pe față și se arată în toată goliciunea manifestărilor sale, bune sau rele, e într-un fel sau altul monstruos (îngrozitor, inacceptabil, dar și- pentru vechii latini, cel puțin- uimitor, magic)." (Chivu 86-87) În această cheie aș privi monstruozitatea naratorului. Astfel, el se arată în toată goliciunea lui, adică în toată transparența lui, așadar, în toată umanitatea lui ${ }^{1}$.

De asemenea, o altă subliniere importantă de făcut este tocmai adaptarea nanocristalelor la alte lungimi de undă ale luminii. Comparați ulterior cu milioane de ochi deschiși, nanocristalele se adaptează la ceva dincolo de realitate, ceva cu adevărat real, accesibil prin transparență. Bineînțeles, aici putem analiza și titlul cărții ce conține în sine un joc de cuvinte: trans și parență, adică dincolo de aparență. (Aș remarca și grafia cuvântului de pe coperta cărții, daca e să ducem acest joc până la capăt. În același mod în care am împărțit eu cuvântul mai sus, apare grafiat și pe coperta romanului:TRANS-PARENT,Ă.)

Așadar, întâlnim un post-om (înțeles ca o evoluție genetică a omului, care depășește prima sa construcție $\mathrm{ADN}$ ) profund uman. Lungimea de undă mai înaltă a luminii la care răspund nanocristalele de guanină ale naratorului este lungimea de undă a luminii emoțiilor, fie ele pozitive sau negative. Ele răspund la umanitatea profundă a emoțiilor, care sunt, în fond, o altfel de lumină.

Încă de la început omenirea a încercat să ajungă la această invizibilitate. Până la această posibilitate apărută în mod biologic, omenirea a testat diverse căi artificiale precum: magia, poțiunile, arta sau sinuciderea:

„Invizibilii. Îi vânam peste tot, îi colecționam, îmi populam paradisul interior cu ei.(...) imaginile care ni se refuză sunt cu atât mai hipnotice, ce nu se vede e cu atât mai prețios, nevăzutele și nevăzuții sunt obiecte de cult. Îi colecționam, prin urmare, pe invizibili cum ar fi colecționat un mistic dement fragmente din Graal.

Pe nicicând văzutul Thomas Pynchon, de pildă.

Pe aproape nevăzutul Salinger. (...)

Pe Georges Melies, care, descoperind absolut întâmplător trucajul (...) a făcut apoi vreo șase sute de filme în care lucrurile dispar neîncetat, plus primul film în care un om se face nevăzut - Escamotage d'une dame, în octombrie 1896-, rămânând în ceea ce-1 privește primul regizor aproape invizibil. (...)

Pe Alexandru Monciu-Sudinski, care, după cele mai bune cărți de proză din România anilor '70, Rebarbor, Caractere și Biografii contemporane, fuge în iulie '78 la Stockholm, iar acolo, devastat de o criză mistică, lasă baltă totul, abandonează realul și se transformă în călugăr rătăcitor, cutreierând vreme de trei decenii Scandinavia, de unde ajung în România, odată la câțiva ani, zvonuri false despre sinuciderea lui (cel mai la îndemână mod de a deveni invizibil, în fond)."

Sau, în altă parte: 
Era documentată invizibilitatea lui Gyges, păstorul lydian pomenit de Glaucon în cartea a doua a Republicii lui Platon, pe la 360 înainte de Hristos- Gyges își folosise în mod criminal invizibilitatea (...) Era certificată menționarea invizibilităţii în Epistola lui Rehoboam (care fusese fiul lui Solomon și nepotul lui David), scrisă de un grec necunoscut cândva în primul sau al doilea secol după Hristos, în care se spunea că invizibilitatea se putea obține scriind o anumită invocație pe un pergament, cu o cerneală mercurială specială, însă numai miercurea la prima oră- fiindcă acestea sunt după cum ne învață Tradiția, ziua și ora lui Mercur, zeul înșelătoriei și al amăgirii.

Această metodă magică pentru a-și face până și manuscrisul invizbil va fi pusă în aplicare de narator, numai că el va întrebuința o altă inscripție, dintr-o altă rețetă de a deveni transparent: „(...) Ca și cum, de fapt, manuscrisul ăsta despre invizibili ar fi el însuși invizibil. (Și firește că e: Isus a trecut+ prin mijlocul lui+ și s-a dus.).",

Până și autorii fațetei anti-umane a proiectului modernităţii erau fascinați de invizibilitate și îi căutau pe cei care reușiseră în mod biologic să o atingă. El capitan, fost membru al securității, este pasionat de subiect: „El capitan reprezenta, așadar, a doua generație de securiști obsedați de oameni și corpuri invizibile.",

O altă metodă de invizibilitate menţionată în citatele de mai sus este sinuciderea. Regăsim trei transparențe la care se ajunge prin sinucidere, care sunt menționate recurent în carte: sinuciderea tatălui naratorului, sinuciderea tatălui lui Radu Vancu (personajul) și sinuciderea lui Radu Vancu. Ei devin transparenți de la prea multe emoții. De aceea, sinuciderea lui Radu Vancu are drept epitaf un vers din Mircea Ivănescu- „,ce frumoasă e moartea'. Și, într-adevăr, este, frumusețea unei morți care te salvează de la a mai simți atât de multe (,,iadul e neputința de a iubide a simţi- și ce frumos-' '), după ce suferința cea mai profundă le-a făcut trupurile invizibile.

Pe lângă modalități de a atinge transparența, ne este oferit și un glosar de posibile substanțe inhibatoare de invizibilitate. Pentru narator, votca este cea mai eficientă substanță de inhibare a transparenței. Din moment ce cristalele guanine se află predominant în ficat, alcoolul devine substanța primară ce poate umple golurile dintre cristale, astfel încât acestea să nu mai reacționeze la emoțiile puternice. Băutura este echivalentul unei anestezii:

„Votca regla singură tot evoluționismul și toată ontologia: pe de o parte, nu-mi lăsa cristalele de guanină să mă extragă din realitate; pe de alta, nu lăsa esența realității săi anuleze existența. Spus mai simplu, nu există ființă - reală sau nu- care să reziste empirismului brut și pozitivist al votcii. Am constatat-o, cu bucurie și teroare, pe pielea mea. Și spun asta nu doar în toate sensurile, ci mai ales literal: am constatat-o pe pielea mea." 
Această cunoaștere corporală, pe propria piele, este un exponent constant în întreaga narațiune: Sibiul are un corp al lui, lumea are un corp, cuvintele au un corp, lumina este un corp dematerializat. Întregul univers este viu și poate atinge trensparența.

În continuare, voi analiza corporalitatea text-cuvânt-lumină. Se va observa că această lumină, privită în diverse răsfrângeri ale sale, va fi legată și de o lumină specifică sinuciderii. Avem de a face cu o adaptare fie a nanocristalelor, fie a modalităţii artificiale de a deveni transparent la diverse tipuri de lumină: fie ca o miere otrăvitoare, fie naturală, fie lumina ce vine din afară versus cea care vine dinlăuntru. De asemenea textul, cuvântul și lumina sunt alese pentru a fi analizate împreună datorită sinonimiei ce se va produce în unele momente între ele.

Corporalitatea text-cuvânt-lumină

La început a fost cuvântul. Şi cuvântul era Dumnezeu. Iisus este lumina lumii. Iisus e lumină. Textul e alcătuit din cuvinte. Așadar, Isus e lumină, deci cuvântul este lumină, și oamenii pot fi lumină, deci transparenți. Cam așa poate fi sintetizat jocul invizibilităților și al corporalităților în ceea ce privește trinomul text-cuvânt-lumină.

Primul invizibil a fost Iisus pe cruce, împreună cu cei doi tâlhari:

„Carnea de pe crucea din dreapta fierbea în clocot, era deja numai un abur- corpul de pe cruce aproape se evaporase, se mutase într-o altă stare de agregare, era practic primul invizibil căruia teroarea și credința îi anulaseră, cât se poate de fizic și de concret, carnea. Primul invizibil căruia trupul i se sublimase- așa cum gheața pusă pe plita încinsă sublimează direct în vapori, fără a mai trece prin starea lichidă, fără a mai avea aşadar nevoie de intermedierea unei alte stări de agregare. Primul invizibil: îl priveam cu teroare și cu enormă invidie."

Descoperirea în copilărie a acestor primi invizibili în Biblia glossy, după cum o numește naratorul, deschide discuția despre corporalitatea cuvântului și despre actul de scriere (ca sângerare) și despre citit (privit ca un fel de autocanibalism). Scrisul copistului este un sacrificiu, o creare de răni prin efortul constant al mâinii ce nu se oprește din notat:

,(...) pe unele dintre ele îmi închipuiam că puteai vedea petele de transpirație sau de murdărie sau de sânge de pe mâinile umflate și crăpate de frig și de efort ale călugărilor copiști, cu articulații inflamate și unghii plesnite; însă, în cazul lor, era un sânge care nu mirosea a tortură, ci a carne fascinată de poveste până la uitarea de sine; adică a credință."

Așadar, mâna/corpul poate deveni transparent prin această uitare de sine pe care o dă povestea prin hipnoză. Corpul sângerează, plesnește, dar este prea captivat de puterea ademenitoare a poveștii pentru a se mai desprinde. Această putere hipnotică a privirii este amintită constant: atât 
privirea cititoarei care îi citește manuscrisul, cât și privirea dilatată a unora dintre strămoșii artiști ce au încercat să devină invizibili. Aceștia, prin privirea lor ce zărea ceva de pe alte frecvențe ale luminii, sunt monstruozități (în sensul enunțat de mine la începutul lucrării):

„(...) (doar la Dostoievski am mai văzut apoi, însă numai la ochiul drept, intensitatea asta insuportabilă a pupilei dilatate- și în portretele care i-au fost făcute în timpul vieții lui de Trutovski, de Perov, de Dmitriev-Kavkazski, dar și în portretul făcut de Vadim Falileev la patruzeci de ani de la moartea lui, adică în 1921, după o fotografie întradevăr stranie, dar de altfel și în toate fotografiile, stranii sau nu, care i-au fost luate în timpul vieții, în toate se vede cât se poate de clar că pupila dreaptă îi e foarte dilatată, ca și când ar fí văzut în fiecare secundă ceva care îi aducea ochiul periculos de aproape de punctul de fierbere; ba, de fapt, și la Milton, îmi aduc acum aminte- atât în portretul făcut lui Milton-copil la zece ani de Cornelius Janssen, cât și în cel al lui Milton postadolescent, făcut de Onslow când poetul englez avea douăzeci și unu de ani, pupila stângă e compusă dintr-o negură subțiratică, deschisă, aproape albăstruie, pe când cea dreaptă e holbată și neagră catran, terifiată de ceea ce vedea neîncetat încă din copilărie; nici nu e de mirare că oameni cu asemenea ochi scriu Demonii și Paradisul pierdut.)"

Privirea fixă, undeva între teroare și credință o avea și mulțimea din fața crucii, pictată în Biblia glossy. Fiind martorii primului invizibil, înțeleg că altă cale nu au decât aceea ca și pielea lor să înceapă să atingă altă stare de agregare. Simpla privire a scenei te putea face invizibil. Ei reușesc să vadă în acel moment ceva mai real decât realitatea. Acest motiv al privirii este regăsit și în formulele magice conform cărora pentru a deveni transparent un ochi trebuie mâncat. Prin ingerarea ochiului, a pupilei dilatate ce vede acel altceva, corpul poate deveni invizibil.

Este de observat lumina glossy care însoțește imaginile din Biblia privită în copilărie de către narator. Nu este glossy în accepțiunea peiorativă a termenului, ce dă în superficial, ci primul sens al termenului ce apare în dicționarul online Merriam Webster, și anume: „having a surface luster or brightness', Această strălucire va da din nou un aspect de sublimare a cărnii textului, a trupului celor de pe cruce:

„Într-un fel care mi se părea straniu atunci, şi de fapt mi se pare la fel de straniu şi acum, sucul acela de carne umană n-a țâșnit niciodată din pagină, pagina n-a început să plângă de mila celui care o adora. Poate fiindcă acel corp se făcuse deja cu totul invizibil- și se mutase cu totul în altă stare de agregare, în altă ordine de existență. În orice caz, am mai auzit, de atunci în coace, carnea umană sfârâind, am văzut corpuri făcându-se transparente sub ochii mei, aproape că am văzut sucul dulce și fierbinte al cărnii omenești țâșnind din pagină ca la icoanele care plâng de mila adoraţiei tale; toate cărțile adevărate sunt îmbibate de sucul ăsta al cărnii omenești, toate au pielița plesnită și tumefiată (iar uneori de-a dreptul invizibilă), literele tuturor compun o crachuelură 
fină și înșelător de regulată, ca și cum ar camufla în spatele lor o pânză străveche și infinit de prețioasă (și firește că exact asta și fac).

Scrisul în sine nu e altceva decât un corp sublimat în zeamă dulce, un corp ce trebuie mâncat atât de cel care scrie, cât și de cititor. Legătura dintre text-scriitor-cititor este una corporală: fiecare este sublimat la rându-i de către lumina ce vine dinăuntrul textului. Ei devin invizibili sub atingerea şi vederea acestei lumini:

„Nu există alt mod de a scrie cărțile adevărate decât acesta: făcându-ți carnea să fiarbă, pielița să crape și să se caramelizeze, îmbibând pagina de sucul dulce și fierbinte al cărnii tale în curs de sublimare. Și nu există nici alt mod de a citi decât acesta: mâncând paginile îmbibate în sucul uman dulce și incandescent, rupând cu dinții din ele ca din felia de pâine în bucătăria de vară a bunicii din Cisnădie, năclăindu-te pe bărbie și arzându-ți limba, înspăimântat de gândul că e doar o chestiune de timp până când și carnea ta va începe să fiarbă, până când și pielița ta va începe să se caramelizeze. (Și firește că o va face.)"

Luminii acesteia ce vine din interiorul textului i se opune lumina suicidară, ca o ,miere otrăvitoare",2 de care sunt înconjuraţi cei treizeci de arginţi ai lui Iuda din tabloul lui Rembrandt, aceeași lumină otrăvitoare care va răzbate din laptopul naratorului ${ }^{3}$. O altă lumină artificială este cea a poeziei lui Vancu, o lumină asemenea beculețelor de Crăciun. Sinuciderea lui redă poemelor sale lumina care le lipsea și de care aveau nevoie. ${ }^{4}$ Lumina amiezii poate ascunde demonul amiezii (depresia, aș spune, cu o trimitere la cartea lui Andrew Solomon-Demonul amiezii) și poate susţine tendința lui nocivă de dezintegrare a lumii. În acest caz, poezia este toxică, transformă totul într-o transparență nedorită, pe care nici măcar băutura nu o poate opri:

„Tot Vancu îmi relatase cândva că Ioan Es. Pop, într-o discuţie de confesional, îi spusese că poezia e toxică și-i povestise despre demonul care dematerializa lumea pe la cinci după-masa, în vremea când tocmai se mutase în Pantelimon, la 113 bis, și bea incontinent de dimineața până la ora la care demonul apărea și mistuia lumea din jurîncât poetul era nevoit să coboare în fața blocului, să îngenuncheze și să se agațe de bordură, singura care mai avea concretețe, pentru a nu se prăbuși în abis."

Alte valențe ale luminii le regăsim în binomul lumina ce vine din interior versus lumina ce vine de la exterior ${ }^{5}$ în capitolul în care apare Sfântul Augustin. Lumina din interior te face invizibil, deci transcendent, pe când lumina exterioară este doar un simulacru, însă fără efectul căutat- acela al transcendenței.

O lumină specială este cea care o însoțește pe Mega pretutindeni. Lumina ei este restauratoare de umanitate: 
„În jurul ei, lumina era atât de fizică, realitatea era atât de reală, încât ai fi zis că tata nu s-a omorât niciodată. Că Iliescu nu distrusese nicicând vreun tată. Sau vreo lume. Ba chiar că nimeni nu murise niciodată pe lumea asta. Era imposibil să mori atâta vreme cât exista o lumină ca aia. Și era implicit imposibil să te sinucizi, sau cel puțin pentru mine devenise imposibil. Dacă lumina aia era posibilă (și iată că era), dacă era posibil ca o pereche de blugi Mustang made in Germany să restaureze toată lumea din jur (și iată, era, de asemenea, posibil), atunci sinuciderea era totuși o trișerie, o modalitate de a da escape înainte de finalul jocului, o reacție de copil bosumflat care își ia mingea și pleacă în toiul meciului pentru că nu îi convine scorul."

Lumina ei restauratoare e aceea care o face o lume, o Singularitate. De aceea în partea care urmează o voi pune pe Mega pe aceeași treaptă cu lumea și orașul. Ea este întruparea universului. Toate se dau după lumina ei, ea este neurotransmițătorul lumii naratorului. Întregul manuscris nu este altceva decât încercarea de a o readuce la viaţă.

Scriam mai sus despre cititul ca act de canibalism. Este un element important pentru că din cauza acestui antropofagism, manuscrisul va trebui tradus în limba norilor pentru a i se putea reda un corp Megăi. Textul reprezintă bucăţi din Mega. Norii, fiind materie translucidă, permit mai lesne trecerea luminii. De aceea, manuscrisul, la rândul său, trebuie să fie translucid pentru a-i permite cititoarei care va citi povestea să o readucă pe Mega la viaţă prin privirea ei hipnotizată, fascinată asupra cuvintelor. (La adevărata viață, cu un corp invizibil.):

„,̂i memorasem, aşadar, Megăi fiecare moleculă a corpului, în aşa fel încât s-o pot reconstrui după catastrofă- iar paginile astea nu sunt altceva, știam asta de la bun început, decât molecule ale corpului ei, rearanjate în așa fel încât, la o anumită trecere a luminii prin ele, cristalele de cuvinte să se încălzească, să se înmoaie, să se facă materie organică fluidă și hipnotică- și să devină, literal și în toate sensurile, Mega."

În partea ce urmează se va observa că Mega nu îl restaurează numai pe narator, ci și orașul, odată cu umanitatea lumii. Plimbările celor doi îndrăgostiți încadrează Sibiul într-o buclă a infinitului. Odată cu aceste plimbări și cu umanitatea redescoperită la Graalaj, post-lumea începe să fie reîmblânzită.

Corporalitatea lume-Sibiu-Mega

În momentul în care naratorul o cunoaște pe Mega, asistăm la nașterea unei noi lumi. Ni se prezintă geneza sub forma unei explozii Bing Bang ce creează noi particule:

„Când Mega s-a așezat lângă mine pe treapta aia roz, cei 1754 de milimetri ai ei au fost tot atâtea gene de novo și ex nihilo deschizându-se brusc în creierul meu, adică alte trei creiere nou-nouțe înflorind în miezul celei vechi; buclele ei negre, tăiate deasupra umerilor, intense ca disperarea ei încă secretă, au devenit neocortexul noii mele lumi; geaca ei de bikeriță, cu nelipsitul pachet de Gauloises în buzunarul de la piept și cu un 
mic steag al Franței pe mâneca stângă, era neurotransmițătorul esențial. Pentru întâia oară, carnea lumii gândea; iar sediul gândirii era corpul ei."

Atunci ia naștere noua lume în care umanul va fi restaurat. Lumea capătă materialitate, mai bine zis, umanitate, și devine corp care gândește. Este de observat faptul că cea care îl va restaura pe narator și lumea acestuia, Sibiul, este fiica lui el capitan, fost securist, deci agent convins al eliminării omului. Toate reprezentările Megăi și ale lumii pe care o încorporează sunt construite pe principiul contrapunctului, care este o expresie a conceptului psihologic de enantiodromie elaborat de Jung și redat de Vancu în Elegie pentru uman. Astfel, Mega și el capitan sunt două poziții contrare care coexistă, două fațete ale aceluiași concept: o faţă dezumanizatoare (el căpitan) și o față restauratoare, profund filo-umană (Mega). Ceea ce tatăl distruge, fiica reconstruiește. Lumina care o însoțește pe Mega este una care curăță, care reface orașul:

„Ceea ce oricine vedea la Mega, de la bun început, era că, într-o lume atât de obiectiv urâtă cum era România anilor '90, ea era tot atât de obiectiv frumoasă. Totul în jurul ei era foarte limpede, chiar și aerul din preajma ei arăta mai curat (,,ca după ploaie', mam gândit cândva), încât ea însăşi dădea senzaţia unui petic luminos de pictură restaurată într-o biserică sufocată de murdărie."

Povestea lor de dragoste, mișcările corpurilor lor, mai precis al Megăi impregnează Sibiul, întreaga lume. Legătura lor cu exteriorul este corporală și modelatoare simultan:

„(...) îmi aduc aminte că ,,a se amesteca” însemna, în româna Bibliilor vechi, a face amor, a-ți amesteca sexele- și-mi spun atunci că „cel luminos amestecat cu cel întunecat'" este numele potrivit pentru felul Megăi de a intra în lume, de a se amesteca erotic cu ea, de a transfera sexualitatea imperialistă a corpului ei fragil asupra tuturor mișcărilor realului- și de a erotiza, în cele din urmă, totul- corpul meu plin de cicatricile Rozei Vânturilor, aerul din jurul nostru când făceam dragoste, blocurile cenușii din Terezian, orașul vechi al Sibiului (...), tot aerul lumii și toate mișcările lumii."

În Elegie pentru uman, Radu Vancu descrie această erotizare a lumii drept un mecanism specific scriitorilor din tipologia corporalului. Încercând să se opună unei lumi mecanicizate, din care umanul este exilat, literatura ajunge să simtă realitatea exclusiv prin simţuri. Lumea va fi gândită corporal și va fi reprezentată asemenea:

Atunci când modernitatea a încercat o evacuare a corpului, literatura a răspuns printro exacerbare a corporalului, prin generarea spontanee a unui număr de scriitori pentru care explorarea sensorium-ului e rațiunea însăşi de a exista. Genul acesta de artist gândește lumea cu corpul, și deopotrivă gândește lumea ca pe un corp. A cărui explorare, irezistibilă, se face cel mai adesea sub forma unei erotici maniacale. (Vancu 67) 
Catedrala gotică din Sibiu devine un corp de piatră, un imens creier ce reunește în construcția sa creierele tuturor celor care au gândit-o. Este istoria vie a mentaltății umane. Sibiul însuși devine un corp care de la atâta teroare începe să se dărâme, deci, în consecință, să devină transparent, la fel cum lumea, sub teroarea lagărelor de exterminare, devenise și ea transparentă odată:

„Sibiul era, de fapt, un splendid oraș invizibil luptându-se să transpară la suprafaţa celui vizibil, care-1 parazita. Fiecare fisură din zidurile coșcovite, fiecare bucată de tencuială plesnită era un marker al invizibilității. Istoria Sibiului era aceaași cu istoria corpului meu- adică istoria unui animal care-și descoperă, cu teroare și deliciu, irealitatea."

În acest joc real-ireal, trupul Megăi devine substanţă revelatoare. Ea fiind cea care a recreat lumea, moartea ei îl va transforma pe narator într-o celulă amorfă, plutind fără țintă în univers, până când privirea cititoarei va traduce textul în limba norilor, iar Mega va reînvia. Întâlnim în această imagistică o rescriere a sacrificiului hristic. Numai că moartea Megăi nu apare ca salvare a lumii, ci ca revelare a adevăratei realități. Trupul ei curăță irealitatea parazitară și revelează (sau chiar restaurează) lumea profund umană ce încerca să răzbată de sub orașul fals construit de teroare:

„Vopseaua începea să se șteargă repede de pe suprafața lumii, precum culorile de pe o pictură falsă a lui Keating atunci când picurai pe glicerina lor câțiva stropi de alcool pur- și bineînţeles că trupul inconștient al Megăi era cel mai pur alcool imaginabil, acolo, în centrul lumii, sub piatra de mormânt a Mirelui, carnea ei dulce și strivită își începuse opera de revelare a falsului fundamental al lumii, de ștergere a aparenței ei de pe pânza invizibilă pe care fusese pictată cu migală și relativ talent de El.”

Rămas singur, naratorul scrie povestea acestei noi lumi restaurate, Biblia unei post-lumi care ia naștere odată cu apariția Megăi și care intră în stagnare odată cu moartea ei. Este o poveste despre renașterea omului, după ce proiectul modernității a distrus-o. La fel cum Adam denumește lucrurile în noua sa lume, așa Mega va denumi obiectele din noua realitate restaurată. În acel stadiu de singurătate paradiziacă, totul capătă un nume: „Niciodată n-a mai fost nimeni atât de singur, matematic vorbind, cum am fost noi doi în anul ăla. Anul postum al transparenței noastre P.T.N., cum 1-a numit Mega. Și, ca tot ce numea Mega, așa a rămas pentru totdeauna.’’

Așa cum Sibiul ia naștere din pielea unui taur, la fel o nouă lume post-Mega va lua naștere din pielea textului. Manuscrisul este o piele care acoperă un spațiu gol, reificat de dispariţia Megăi. Naratorul devine copistul Lui. Rescrie istoria unei lumi, pe care privirea Lui, împreună cu a cititoarei, o va face reală: 
„Chiar acum, în mansardă, în vreme ce scriu toate frazele astea transparente, la bătrânul meu laptop Dell, îmi ridic ochii spre el- e tot acolo, pe desktopul întunecat (fiindcă e aproape patru dimineața), așteptând să închei manuscrisul ăsta, ca să îl traducă în limba norilor, ca să îl întindă în sfârşit complet deasupra lumii, ca să mă poată alătura și pe mine, ultimă frază transparentă, în manuscrisul la care, singur de atâtea eternități, se tot muncește."

Pe tot parcursul narațiunii, revine constant această imagine a unui ochi ce privește totul, care scrie sau rescrie lumea, care formatează ideile personajelor. Nu știm cine este acest ochi ce privește pasiv totul: poate fi cititoarea? Sau un Dumnezeu ce își urmărește creația ca pe un spectacol? Altceva? Motivul ochiului, după cum am arătat mai sus, este direct legat de transparență: ingerarea de ochi te poate face invizibil printr-o anumită formulă magică, iar pupila dilatată din ochii anumitor scriitori (Dostoievski și Milton) arată că ei vedeau dincolo de realitatea comună. Pupila lor, asemenea cristalelor de guanină, se adaptase pentru a vedea ceva dintr-o altă undă de rezonanță a luminii. În final, Mega nu va fi transparentă fară ochiul cititoarei care va permite luminii să treacă prin cuvintele (traduse în limba norilor) manuscrisului:

„Știu bine că el e doar o traducere a Megăi în limba cuvintelor, inutilă și ineficientă și ridicolă ca toată literatura în care cândva am crezut amândoi mistic; însă sper că, atunci când va fi încheiat (adică acum, peste doar zece-douăzeci de rânduri), cineva o să înceapă de îndată să îl traducă în limba norilor; că, de îndată ce voi tasta ultima lui literă, mă voi prăbuși pe tastatură, strivit de sutele de tone de moloz verbal și misticiar cineva, a cărui iconiță va continua până atunci să zâmbească ironic în colțul din dreapta sus al cerului, la fel de ironic și de tandru cum zâmbești chiar acum tu, draga mea cititoare mistică și invizibilă (fiindcă și ochii tăi contează decisiv în micul meu pact), cineva, așadar, va începe să mă traducă și pe mine în limba norilor. Dacă mai e posibil vreun pact cu literatura, atunci pactul meu mic și ridicol ăsta e: să-mi construiesc singur turnul care să mă strivească, turnul de cuvinte prin inima cărora Jesus passant par le milieu d'eux s'en alloit- iar el să-mi strivească cu oricâtă ură fiecare milimetru pătrat de carne- pentru ca, în schimb, cineva să ne traducă, pe mine și pe Mega, în limba norilor, să devenim amândoi lumină pentru ochi bolnavi (ceea ce corpul Megăi, a fost, de fapt, de la bun început)."

Așadar, în final, naratorul și Mega vor fi eliberați din corpurile lor false și vor atinge transparența, devenind nori translucizi la picioarele Lui. Odată legiunea de nori completă, va avea loc A Doua Venire, când naratorul va revedea ochii Megăi. Din nou, apare această imagistică a ochiului ca o lume întreagă, de sine stătătoare. Trebuie observat că în încercarea sa de a deveni complet transparent, scăpând de corpul lui vizibil, şi redându-i și Megăi invizibilitatea de o corporalitate translucidă, povestitorul folosește toate mijloacele pentru a se asigura că toate acestea 
se întâmplă. Avem utilizarea formulei magice (Isus a trecut prin mijlocul lor și s-a dus), puterea literaturii de a face tot ce conține transparent, aducând carnea la punctul de fierbere în care se sublimează și ochiul cititoarei care, prin dilatarea pupilei, va reuși să vadă o altfel de lumină și va traduce manuscrisul din fața ei în limba norilor. În acest mod, totul este conectat.

Elementul corporal se intersectează pe tot parcursul narațiunii cu acela al confesiunii, al maximalității, al sacralităţii și al poeticităţii. Se construiesc reciproc și se află în interdependență în cadrul narațiunii din Transparența. Trebuie menţionat că, din motive de argumentare, am operat o delimitare a acestora (când acestea apar într-o constantă interdependență), pentru a prezenta cât mai structurat conturarea postumanismului și post-omului în textul lui Radu Vancu.

Confesiunea (și, implicit, tipologia confesivă), ca stil, este omniprezentă. Avem în faţă povestea de dragoste într-o post-lume ce este restaurată prin redescoperirea emoțiilor pozitive umane. Lumea e redescoperită prin alt om, care devine centru al noii lumi, care fusese deposedată de umanitate. Umanitatea este complet redescoperită și în ceilalți. Toate personajele de la Graalaj (securistul, escorta de lux, barmanița, profesorul universitar, spionul, fostul pilot, sudorul) sunt profund umane, iar descrierea lor ocupă pagini întregi. Sunt niște artiști, ultimii oameni sensibili rămași în viață după un potop al terorii:

„L-am privit admirativ- și el era, la rândul lui, un artist, cum eram la urma urmei toți cei din Graalaj. Artiști ai foamei, ai alcoolului, ai minciunii, ai răului, sub toate formele lui. Ba chiar și artiști ai purității, ca Ilie (...)"

Categoria maximalistă este reprezentată tocmai de aceste personaje din Graalaj, de discuțiile lor filosofice sau polemice despre artă, viață, politică, religie. Toate valorile cunoașterii sunt reintroduse în discuție cu voracitate. Ceea ce nu putea fi discutat, citit, aflat înainte, în perioada restrictivă a comunismului, iese la suprafață cu fervoare acum, în această post-lume ce caută să își regăsească umanitatea.

Categoria sacrului este reprezentată prin mistica transparenței ca formă de transcendență. Primul invizibil a fost lisus pe cruce, iar de atunci omenirea a încercat să atingă, în diverse moduri, transparența. Dar aceste căutări au fost camuflate fie sub forma artei, fie sub forma magiei, fie sub forma sinuciderii. Mega și naratorul cred și trăiesc după această mistică a literaturii, care are puterea de a trece corpul într-o altă stare de agregare. Aceeași funcție o are și lumina, privirea. Întâlnim în roman și o mistică negativă, ocultă, aceea a surâsului lui Iliescu, care devine un cod pentru masoneria anti-umană:

„Îmi e ușor să-i văd, zâmbind toți cu zâmbetul lui Iliescu, trecut de pe o față pe alta ca o parolă comună a enormei și eternei masonerii împotriva suferinței, zâmbind, așadar, 
cu zâmbetul acela care ne-a măcelărit istoria recentă, zâmbind cu gura până la urechi în fața gropilor comune- care pentru ei sunt la fel de inexistente ca măcelul Troiei, sau al pruncilor din Betleem. Fiecare zonă a lumii atinsă de suferință se face neîntârziat pentru ei transparentă (...)"

De data aceasta, valența transparenței este negativă. Este o transparență artificială, cauzată de dorința lor de a nu vedea rezultatul proiectului dezumanizant al modernității. De aceea, lumea trebuie salvată prin umanizare sau prin poeticizare. Astfel, ajungem și la cea de a cincea categorie.

Am vorbit în prima parte a lucrării despre funcția extratextuală a acestei poeticități. În plan intratextual, poeticitatea are funcția de a restaura lumea. Ea vine sub forma sacralității, a misticii literaturii. Realitatea, văzută printr-un filtru poetic, renaște. Mega îl barrettiza pe Jim Morrison, pe Rimbaud, ea făcea dragoste în același mod barrettizat. Ea privea totul prin filtrul poeziei și al cântecului, al traducerilor pline de influențe eclectice. Cântarea de versuri a Megăi e ceea ce declanșează o restaurare a naratorului:

„Ochii ei verzi-căprui erau încercarea disperată de a păstra la suprafaţă o civilizație care se scufundă. Murdar de sânge și îmbâcsit de transpirație după ore întregi de descărcat camioane cu zahăr sau cu făină sau cu ouă, mă simțeam obiectiv curat atunci când cântam cu ea versurile lui Morrison și Waters pe treptele facultății. Simțeam cum începe să mă restaureze și pe mine cineva."

Întâlnim din nou această imagistică a ochiului, care, de data aceasta, nu provoacă transparența, ci apără lumea de la înec. Privirea Megăi va fi prezentă peste tot, chiar și în grădina Graalajului, unde va crea din vegetaţie un ochi imens, negru, în care toată materia lumii este atrasă și care era făuritor atît de coșmare, cât și de vise. Ochiul din curtea Graalajului se schimba în funcție de cel care îl privea.

Reunind tipologiile cu care literatura s-a opus anti-umanului, Radu Vancu creează o narațiune restauratoare: de oameni, de realitate, de cititori și de naivi ce încă mai cred în diferite pacte cu literatura.

\section{Concluzii}

Aflat în faţa alegerii a ceea ce va însemna postumanul și postumanismul pentru el, Radu Vancu se poziționează de partea unui postumanism care va transfera calităţile umanului (empatie, compasiune, solidaritate) asupra non-umanului (înţeles ca natură, artă, oraș, clădiri). Astfel, vegetația Graalajului va imortaliza plăcerea și suferința umană, prinzând viață și deplângându-i în fiecare noapte povestea, Sibiul va deveni un oraș viu, născut din aceeași materie a invizibilității naratorului, catedrala gotică devine un creier de piatră, subsumând toate mințile care au gândit-o și 
imaginat-o, iar arta se sublimează, devenind una cu lumina. Toate aceste corporalități, în variațiile lor, nu sunt altceva decât o transferare de umanitate, o îmblânzire a lor. În noua postlume, ele ajung să fie într-adevăr după chipul și asemănarea celui care le privește, a aceluia care le gândește.

De asemenea, corporalitatea textului, în special, poate fi privită drept o rămășiță a teoriei franceze, pe care Radu Vancu o situează la originile postumanismului. Mai mult, însuflețirea vegetalului și situarea diverselor specii din natură pe aceeași scară evolutivă cu naratorul transparent marchează redefinirea poziției omului în noul sistem și a legăturii acestuia cu naturalul. Zona inovației tehnologice, menționată de Radu Vancu în eseul său „Postumanul. Mic manual de întrebuințare', este și ea prezentă în Transparența prin mutația genetică suferită de narator. Această mutație nu ține de o tehnologie per se, creată artificial de umanitate, ci de o tehnologie biologică, declanșată de întreaga omenire prin supunerea constantă la teroare. Aceasta declanșează noua dezvoltare pentru adaptarea la tot ceea ce înseamnă sentimente puternice, trăire excesivă. Omenirea reușește să evolueze prin empatia reciprocă, ce devine scut în fața unei amenințări externe.

Astfel privind Transparența, postumanismul literar la Radu Vancu se conturează drept o reacție din cadrul postmodernității împotriva anti-umanității proiectului modernității. Post-omul este o evoluție genetică a omenirii în fața terorii, învățând să comunice cu naturalul și să preia de la aceasta metoda de întrebuințare a cristalelor guanine. Nu este un hibrid între om și mașină, ci un om profund uman, chiar excesiv. El trăieşte totul până la transparență. Post-umanitatea este rezultatul anilor de teroare sub regimurile totalitare, iar post-lumea este încercarea omului transparent de a restaura și repopula spațiul din care a fost scos. În fond, postumanismul privit astfel este profund uman, o restaurare a lumii prin infuzarea de calităti umane în toate.

\section{Bibliografie}

Askin, Ridvan. „Objects”, The Cambridge Companion to Literature and the Posthuman, coordonat de Bruce Clarke și Manuela Rossini, Cambridge University Press, 2017, pp.170-181. Bâlici, Mihnea, „Transparent și străveziu”, www.observatorcultural.ro, accesat la data de 12 octombrie 2020, adresa URL: https://www.observatorcultural.ro/articol/transparent-si-straveziu/. Chivu, Marius. Ce-a vrut să spună autorul. Iași :Polirom, 2013.

Ciorogar, Alex (coordonator). Postumanismul. București:Tracus Arte, 2019. 
Clarke, Bruce. „The Nonhuman’, The Cambridge Companion to Literature and the Posthuman, coordonat de Bruce Clarke și Manuela Rossini, Cambridge University Press, 2017, pp. 141-152.

Colebrook, Claire. „Futures”, The Cambridge Companion to Literature and the Posthuman, coordonat de Bruce Clarke și Manuela Rossini, Cambridge University Press, 2017, pp. 196-208.

Cristea-Enache, Daniel, „Fără busolă’, www.romanialiterara.com, accesat la data de 12 octombrie 2020, adresa URL: https://romanialiterara.com/2019/08/fara-busola/.

Romila, Adrian G., „Cartea transparențelor”, www.lapunkt.ro, accesat la data de 12 octombrie 2020, adresa URL: https:/www.lapunkt.ro/2018/12/cartea-transparentelor/.

Rossini, Manuela, „Bodies', The Cambridge Companion to Literature and the Posthuman, coordonat de Bruce Clarke și Manuela Rossini, Cambridge University Press, 2017, pp. 153-169.

Sălcudean, Minodora, „Radu Vancu, Transparența- romanul po(i)etic al unei minți diamantine”, www.capitalcultural.ro, accesat la data de 12 octombrie 2020, adresa URL: https://capitalcultural.ro/radu-vancu-transparenta-romanul-poietic-al-unei-minti-diamantine/.

Stroe, Luana, „Lumile cristaline - <<Transparența $>>$, de Radu Vancu’, www.bookaholic.ro, accesat la data de 12 octombrie 2020, adresa URL: https://www.bookaholic.ro/lumile-cristalinetransparenta-de-radu-vancu.html.

Vancu, Radu. Elegie pentru uman: o crtică a modernității poetice de la Pound la Cărtărescu. București: Humanitas, 2016.

Vancu, Radu. Transparența. Humanitas: București, 2018. 